Journal of Vocational Nursing

www.e-journal.unair.ac.id/JoViN/

\section{RELATIONSHIP KNOWLEDGE OF DIABETIC FOOT CARE WITH THE OCCURRENCE DIABETIC ULCER IN PUSKESMAS TEGUHAN}

\author{
Sukma Ayu Indrianisa' and Raudhotun Nisak ${ }^{2}$ \\ ${ }^{1,2}$ Akademi Keperawatan Pemerintah Kabupaten Ngawi
}

Research Report

Introduction: Diabetes mellitus is a condition in which the body is unable to produce insulin so hyperglycemic. Uncontrolled hyperglikemi can result in several complications, one of which occurs in diabolical ulcers or leg injuries. Prevention of diasecond ulcers can be done by controlling blood sugar levels, exercising, and undergoing foot care. Knowledge of foot care needs to be known by diabetics in order to minimize the risk of diabetic ulcers. The purpose of this study is to know the level of knowledge of foot care in diabetics mellitus with the occurrence of diabetic ulcers. The design used is a scriptive correlation with the cross sectional approach. Methods: The technique of taking sambel with accidental sempling with a sample of 73 respondents. Analyze data using chi square. Results: The results of the study obtained as many as 40 reseponden (55.8\%) knowledgeable and 50 respondents (68.5\%) did not have a diabetikum ulcer. The results of the chi square analysis test obtained Pvalue $=0,000$ which showed that there is a link between the knowledge of foot care and the incidence of diabetic ulcers in diabetics mellitus. Conclusion: From the results of this study, diabetics are expected to perform foot treatment so as to reduce the risk of diabetic ulcers.

\section{ARTICLE INFO}

Recived 20 October 2020

Accepted 28 October 2020

Online 29 October 2020

*Correspondence:

Sukma Ayu Indrianisa

*Email:

nisak.arif@gmail.com

Keywords:

Diabetes Mellitus, Diabetic Ulcers, Foot Care.

\section{INTRODUCTION}

Diabetes mellitus (DM) is one of the chronic diseases characterized by increased levels of sugar in the body (hyperglymi) due to insulin inadequacy as well as the body's inability to produce insulin (Srimiyati, 2018; Amalia et al, 2018). Long-term and uncontrolled hyperglycemia can cause damage to the body system, especially the nervous system and blood vessels such as arterosclerosis, thickening of basal membranes and changes in peripheral nerves. This can trigger diabtic or gangrene ulcers (Hudiyawati and Riski, 2018; Triyoga and Hutabarat, 2015). Severe diasecond ulcers may be at risk of amputation (Permadani, 2017). In Indonesia there were $23 \%$ deaths from gangrene ulcers in diabetics while in the event of amputation as much as $30 \%$, in addition the importance of knowledge related to diabetic foot care is still limited. In response to this lack of knowledge about foot care is one of the factors of the increase in diabtic ulcers as well as the incidence of amputations (Permadani, 2017; Srimiyati, 2018).
Prevelence of diabetic mellitus increases from year to year. Data from the World Health Organization (WHO) in 2014 showed 422 million people worldwide with diabetes mellitus and are expected to see an increase of 629 million people by 2042 (WHO, 2019). Data from RISKESDAS in 2018 in Indonesia there are 1,017,290 diabetics mellitus. Prevelensi diabetes mellitus in East Java placed second only to West Java with a total of 151,878 inhabitants with a percentage of $2.0 \%$ (Kementrian Kesehatan Republik Indonesia, 2019). Data from Ngawi District Health Office in 2019 states that there are 18,469 people with diabetes mellitus who are realized doing treatment in health services (Dinas Kesehatan Kab Ngawi, 2019). People with diabetes mellitus in December in the working area of Puskesmas Teguhan a total of 1,279 people.

In patients with DM with uncontrolled sugar levels will result in complications if they do not get the right treatment. Common complications include vascular abnormalities, retinopathy, nephropathy, neuropathy and diabetic wounds. Diabetikum wounds or known as 
diable ulcers are chronic wounds that are difficult to heal. Neurological disorders (neuropathy) and vascular disorders of the limbs cause marked tissue damage to the decrease in pain sensation, changes in leg shape, calus formation, leg muscle atrophy, decreased blood flow that brings oxygen and nutrients to the tissues (Simarmata,2018). Diabetikum ulcer is very easy to get an infection if not immediately carried out treatment and treatment, this infection can be widespread even amputation (Chrisanto, 2017). Knowledge of diabetes mellitus is one of the basics that diabetics must know in order for the sufferer to change his behavior and be able to perform appropriate treatment with his disease (Azim, 2016).

Low knowledge of foot care can lead to the prevention of diabolical ulcers. The legs of diabetics if left un treated will be easily wounded and quickly develop into ulcers due to the lack of pain sensation so that sufferers do not realize and ignore the onsans (Srimiyati, 2018; Rahmawati, 2017)). According to research conducted by Srimiyati in 2016 it is mentioned that there is a significant link between knowledge and foot care in diabetics. Diabetic patients with good knowledge of foot care have a 4,767 greater chance of undergoing foot care to prevent diabetic ulcers (Srimiyati, 2018).

Preventive measures need to be made in patients with diabeles melitus so that there is no diabetic ulcer. Foot care is one of the efforts to prevent the risk of ulcers, which can be done by checking the condition of the feet every day, cutting nails properly, using comfortable footwear, moisturizing the feet and maintaining foot hygiene (Tini, Setiadi and Noorma, 2019). In diabetic foot care is important to do because the foot is a buffer of the body that has many nerves to connect to other organs, and the foot is an organ of the body that easily occurs wounds. This is the background of researchers to learn more about the relationship of foot care knowledge with the incidence of diabetic ulcers in diabetics mellitus in the working area of Puskesmas Teguhan Sub-District Paron Ngawi.

\section{MATERIALS AND METHODS}

This research is a type of corelational research with cross sectional method which is a study that aims to see the relationship between variables and the way data is retrieved at a time (Notoatmodjo, 2010). This research was conducted to find out the relationship between the level of knowledge of foot care and the incidence of diabetic ulcers of DM sufferers. The population in this study is diabetic mellitus in the area of Puskesmas Teguhan Sub-District Paron Ngawi. The sample used in this study was 73 respondents using accidental sampling techniques. The research instrument used to measure respondents' knowledge is the Nottingham Assessment of Funcional Footcare (revised 2015) questionnaire that has been translated and modified by Arifah (2018). As for knowing whether there are diabtic ulcers using wagner-ulcer classication ulcer degree observation sheet and the University of Texas Wound Classification (Boehm, R. 2017). Data analysis is done using univariate analysis, to find out the distribution of each variable and bivariate to determine the relationship between variables.

\section{RESULTS}

Table 1 Distribution Frequency of Knowledge of Diabetic Foot Care and Occurence of Diabetikum Ulcers in Respondents $(\mathrm{N}=73)$

\begin{tabular}{ccc}
\hline Variabel & Frequency & Percentage (\%) \\
\hline $\begin{array}{c}\text { Knowledge of Diabetic Foot Care } \\
\text { Good } \\
\text { Lack }\end{array}$ & 33 & \\
& 40 & 45,2 \\
& & \\
\hline & & \\
The Occurrence of Diabetikum Ulcers & & \\
Ulcer & 23 & 61,5 \\
No Ulcer & 50 & \\
& & 68,5 \\
\hline
\end{tabular}

Shows that as many as 40 people (55.8\%) have less knowledge about foot care in diabetics, whereas based on observations conducted by researchers obtained 23 people (31.5\%) had a diabetikum ulcer. 
Table 2 Results Analysis of Relationship Knowledge of Foot Care with Diabetic Ulcer Occurence in Diabetics Mellitus in Puskesmas Teguhan ( $\mathrm{n}=73$ )

\begin{tabular}{|c|c|c|c|c|c|c|c|}
\hline \multirow{3}{*}{$\begin{array}{l}\text { Knowledge of Foot } \\
\text { Care }\end{array}$} & \multicolumn{4}{|c|}{ The Occurrence of Diabetic Ulcer } & & & \multirow[b]{2}{*}{ Pvalue } \\
\hline & \multicolumn{2}{|c|}{ Ulcer } & \multicolumn{2}{|c|}{ No Ulcer } & \multicolumn{2}{|c|}{ Amount } & \\
\hline & $\mathbf{N}$ & $\%$ & $\mathbf{N}$ & $\%$ & $\mathbf{N}$ & $\%$ & \multirow{4}{*}{0,000} \\
\hline Good & 1 & 4,3 & 32 & 64,0 & 33 & 45,2 & \\
\hline Lack & 22 & 95,7 & 18 & 36,0 & 40 & 54,8 & \\
\hline Total & 23 & 100 & 50 & 100 & 73 & 100 & \\
\hline
\end{tabular}

Shows that of the 40 respondents who had less foot care knowledge, there were 22 respondents $(95.7 \%)$ ulcers. While of the 33 respondents who had good foot care knowledge, there were 18 respondents $(36.0 \%)$ that does not have a diabetic ulcer. The data analysis results using the chi-square test showed a significant value between two variables with a yield of pvalue $=0.000(p<0.05)$. This indicates a link between the level of knowledge about foot care and the incidence of diabetic ulcers in diabetics mellitus in the working area of Puskesmas Teguhan.

\section{DISCUSSION}

\section{Knowledge of Foot Care in Diabetics Mellitus.}

The results of this study show that most respondents have less knowledge. This result is in line with oktorina et al research (2019) that the knowledge level of respondents is less than $62.9 \%$ or as many as 22 out of 35 respondents. Similar results were also shown in Hanifah's research, et al (2019) where only 9 respondents were knowledgeable less than a total of 36 respondents.

Knowledge is an important part of behavioral formation. This is because knowledge affects the mindset so much that in doing everything, including how to analyze the disease that occurs in him depends heavily on the knowledge he has (Arikunto in Hanifah et al, 2019). Knowledge related to foot care needs to be known by diabetics such as daily foot examination to know the condition of the feet, cutting the correct nails, using good footwear, maintaining foot hygiene and foot gymnastics (Ayu, 2017).

The level of restraint is one of them influenced by formal education (Srimiyati, 2018). Notoadmojo (2010) in Tini et al (2019) says that education levels have an important role to play in receiving and understanding information. Based on the results of research conducted Oktorina et al (2019) said that someone who has higher education tends to have good knowledge. Conversely respondents who have a low education tend to have less knowledge, therefore knowledge can be influenced by the level of education.

In this study it is known that almost all respondents have never had foot counseling before. According to research conducted by Yotsu et al (2014) in Permadani (2017) said that less knowledge about the treatment or prevention of diabetic leg wounds due to lack of information about the treatment and complications of diabetes mellitus. Diabetics can follow counseling on foot care and how to recognize the characteristics of diabetic ulcers as well as the complications that can be granted.

Incidence of diabetic ulcers in diabetic mellitus

The results of this study showed a small percentage of respondents experienced diabtic ulcers. According to Ayu (2017) diabetic ulcers are wounds that occur in the legs of diabetics that occur due to peripheral and autonomic nerve disorders. There are several reasons that cause diabetics to be at risk of diaberic ulcers such as sensory neuropathy so that sufferers do not feel if there are injuries to the legs, ischemic disorders that result in a long wound healing process, as well as immunity disorders.

In this study, respondents who had diabtic ulcers were more than 50 years old. From research conducted by Hudiyawati \& Riski (2018) stated that the highest frequency of diabetics is the age group 56-65 years which shows most respondents in the elderly group. This is supported by research conducted by Apriliyani (2018) showing that most respondents have a $>40$ years old.

According to research conducted by Nurhanifah (2017) obtained results there is a link between age and the incidence of diaphical ulcers. Some risk factors affecting diabetic ulcers include 
diabetes, obesity, uncontrolled blood sugar levels, dietary disobedience, physical exercise (exercise), irregular treatment, and foot care and a history of suffering from ulcers (Mustofa, 2016). Getting older leads to decreased physiological bodily functions in diabetics so that there can be a decrease in secretion or insulun rest resulting in the ability of the body's function to control high blood glucose levels is less than optimal. While in the condition of uncontrolled blood sugar levels and occurring in a prolonged period of time can result in various complications such as leg injuries or diabetikum ulcers.

\section{The Relationship of Knowledge of Foot Care with the Occurence of Diabetic Ulcers in Diabetics Mellitus.}

The results of chi square analysis obtained the results of the coefficient Pvalue $=0,000$ so that Ho was rejected (Pvalue $<0.005$ ). The results of this study are in line with research conducted by Fauziyah (2012) that there is a link between the knowledge of diabetes mellitus type 2 patients about the risk of diabetic ulcers and the incidence of diabetic ulcers in Dr. Moewardi Hospital. Knowledge of foot care in diabetics can be influenced by long-suffering diabetic $>$ s. A person who has diabetes mellitus $>5$ years is expected to have good knowledge to do health care. Therefore, diabetics are older can study behavior based on previous experience so as to control blood sugar levels so as not to experience various complications (Azim, 2016; Suryati et al, 2019). So a good knowledge of health care is needed to prevent any complications.

Meanwhile, people with diabetes who have a long $<5$ years are also at risk of having diabetic ulcers. Lack of knowledge and awareness to control blood sugar levels as well as through foot care such as checking shoes before use, drying between toes, using proper footwear both inside and outside the house, moisturizing the feet, and doing foot gymnastics to trigger the onskin ulcer (Tini, Setiadi and Noorma, 2019). However, if you have good knowledge to treat your feet and keep blood sugar stable, it will decrease the reriko of the dialectical ulcer as well as damage to nerve tissue in the legs.

Knowledge is necessary to shape an attitude and change a person's behavior, In diabetics knowledge of foot care needs to be known to prevent the onskin ulcer or complications that can result from amputation. Forms of foot care that diabetics need to know include washing their feet with warm water, carrying out daily foot checks, drying the feet to the toes, undergoing daily foot checks to determine changes in the feet, and using proper footwear (Srimiyati, 2018). Lack of knowledge about foot care in diabetics is one of the factors in the on-the-condition ulcer. The importance of information on how to treat the feet needs to be known by diabetics to take prevention from the beginning.

\section{CONCLUSION}

The results of this study show that there is a link between the knowledge of foot care and the incidence of diabetic ulcers in diabetic mellitus in the working area of Puskesmas Teguhan SubDistrict Paron Ngawi. For diabetics it is recommended to increase knowledge about diabetes as well as do foot care, such as always checking the feet daily, cutting nails every week, using footwear every day, always cleaning the toes, using moisturizer, using socks when wearing shoes. In addition, it is also important for health workers to always provide knowledge for DM sufferers, especially about the prevention of diabetic ulcers and how to treat the legs so that there are no complications such as amputation.

\section{REFERENCES}

Amalia, Yunita, Lintang Dian Saraswati, Muflihatun Muniroh, and Ari Udiyono. 2018. "Hubungan Pengetahuan, Dukungan Keluarga Serta Kejadian Ulkus Kaki Diabetes ( Studi Di Wilayah Kerja Puskesmas Ngesrep Semarang)." Jurnal Kesehatan Masyarakat 6. http://ejournal3.undip.ac.id/index.php/jk m. Diakses pada taggal 21-12-19 pukul 14.00 WIB.

Apriliyani, Sigit. 2018. "Hubungan Tingkat Pengetahuan Dan Sikap Dengan Perilaku Pencegahan Terjadinya Luka Kaki Diabetik Pada Penderita Diabetes Melitus Tipe II."Skripsi.Universitas Muhammadiyah Surakarta. Fakultas IImu Kesehatan

Arifah, Nihlatun. 2018. "Pengaruh Program Training Foot Care Terhadap Perilaku Perawatan Kaki Diabetes Melitus Anggota Prolanis Puskesmas Kasihan II."Skripsi. Universitas Muhammadiyah Yogyakarta.

Ayu, Shinta Arini. 2017. "Hubungan Perawatan Kaki Dengan Kejadian Luka Kaki Pada Penderita Diabetes Melitus Di Rsud Dr . H . Abdul Moeloek Provinsi Lampung Tahun 2015." Jurnal Kesehatan Holistik 11(2): 95-100.

Azim, Lalu Muhammad Arsil. 2016. "Hubungan Tingkat Pengetahuan Pasien Diabetes Melitus Tipe 2 Tentang Perawatan Kaki 
Dengan Klasifikasi Risiko Ulkus Diabetik Di Poliklinik Rsud Panembahan Senopati Bantul."Skripsi. Sekolah Tinggi IImu Kesehtan Jederal Achmad Yani.

Boehm, R. 2017. Diabetic Foot Ulcer Classification Systems A Review of The Literature, DARCO, (1975), 1-14

Chrisanto, Eka Yuda. 2017. "Hubungan Tingkat Pengetahuan Dengan Sikap Perawat Tentang Perawatan Ulkus Diabetik Dengan Metode Moise Wound Healing Di RSD Mayjend H.M.Ryacudu Kotabumi Lampung Utara Tahun 2017." Jurnal Kesehatan Holistik 11(2): 123-31.

Dinas Kesehatan Kabupaten Ngawi. 2019. Data Penyakit Tidak Menular Tahun 2019. Ngawi : Bidang Pencegahan dan Pengendalian Penyakit Dinas Kesehatan Kabupaten Ngawi

Hanifah dkk. 2019. Hubungan Tingkat Pengetahuan dengan Kejadian Ulkus Diabetik pada Pasien Diabetes Mellitus di Ruang Seruni RSUD dr.M.Yunus Bengkulu.Jurnal SMART Keperawatan, 6(2) : 141-147

Hudiyawati, Dian, and Sabila Riski. 2018. "Pengetahuan Berpengaruh Terhadap Kepatuhan Dalam Perawatan Kaki Pada Klien Diabetes Melitus Tipe II."

Kementrian Kesehatan Republik Indonesia. 2019. Laporan Nasional RISKESDAS 2018. Jakarta: Lembaga Penerbit Badan Penelitian dan Pengembangan Keehatan (LPB).

Mustofa, Irwan A. HI. 2016. "Determinan Epidemiologis Kejadian Ulkus Diabetik Pada Penderita Diabetes Melitus Di RSUD Dr. Chasan Beosoire Dan Diabetes Canter Ternate."

Notoatmodjo, Soekidjo. 2010. Promosi Kesehatan Dan Perilaku Kesehatan. Jakarta: PT RINEKA CIPTA.

Nurhanifah, Dewi. 2017. "Faktor-Faktor Yang Berhubungan Dengan Ulkus Kaki Diabetik ( Factors Related To Diabetic Ulcers Legs In Policlinic Of Diabetic Leg )." 1(1): 32-41.

Oktorina, Rola, Aria Wahyuni, and Ervina Yanti Harahap. 2019. "Faktor Yang Berhubungan Dengan Perilaku Pencegahan Ulkus Diabetikum Pada Pasien Diabetes Melitus." REAL in Nursing Journal 2: 108-17. https://ojs.fdk.ac.id/index.php/Nursing/i ndex. Diakses pada tanggal 21-12-19 pukul 14.15 WIB
Permadani, Agista Delima. 2017. “Hubungan Tingkat Pengetahuan Tentang Ulkus Diabetik Dengan Pencegahan Terjadinya Unkus Diabetik Pasa Pasien Diabetes Melitus Di Persadia Rumah Sakit Dokter Soeradji Tirtonegoro Klaten." Skripsi. Universitas Muhammadiyah Surakarta.Fakultas Ilmu Kesehatan

Rahmawati, Umi Nur. 2017. "Hubungan Tingkat Pengetahuan Tentang Ulkus Diabetik Dengan Perawatan Kaki Pada Penderita Diabetes Melitus Di Persadia Cabang Kota Surakarta." Sripsi. Universitas Muhammadiyah Surakarta.Fakultas IImu Kesehatan

Simarmata, Mesrida. 2018. “Tingkat Pengetahuan Pasien Diabetes Mellitus Terhadap Terjadinya Luka Diabetikum Di Rumah Sakit Umum Marthafriska Pulo Brayan Medan Tahun 2018." Excellent Midwifery Journal 1(2): 32-40.

Srimiyati. 2018. "Pengetahuan Pencegahan Kaki Diabetik Penderita Diabetes Melitus Berpengaruh Terhadap Perawatan Kaki." 16(2): 76-82.

Suryati, Ida, Def Primal, and Darsis Pordiati. 2019. "Hubungan Tingkat Pengetahuan dan Lama Menderita Diabetes Melitus (DM) Dengan Kejadian Ulkus Diabetikum Pada Penderita DM Tipe 2." 6: 1-8.

Tini, Rizky Setiadi, and Nilam Noorma. 2019. "Mengurangi Resiko Kaki Diabetik Pada Pasien Diabetes Melitus Tipe 2." Jurnal Citra Keperawatan 7(1). http://ejurnalcitrakeperawatan.com.

Triyoga, Akde, and Ricsen Hutabarat. 2015. "Senam Kaki Diabetes Meningkatkan Reflek Plantar Pada Pasien Diabetes Melitus Tipe II." 3: 176-85.

World Health Organization (WHO). 2019. Classification Of Diabetes Mellitus. WHO. https://apps.who.int/iris/rest/bitstreams/ 1233344/retrieve 